\title{
Adolescents' Physical Education Literacy Level Due Developmental, Humanistic and Fitness Factors.
}

\author{
Bebeley Samuel Joseph (PhD Scholar) ${ }^{1}$, Laggao Sam Augustine $(\mathrm{PhD})^{2}$, \\ Tucker Henry Joe ${ }^{3}$, \\ ${ }^{1}$ Lecturer, Department of Human Kinetics and Health Education, School of Education, Njala University, PMB \\ Freetown, Sierra Leone \\ ${ }^{2} H O D$, Department of Human Kinetics and Health Education, School of Education, Njala University, PMB \\ Freetown, Sierra Leone \\ ${ }^{3}$ Lecturer, Department of Human Kinetics and Health Education, School of Education, Njala University, PMB \\ Freetown, Sierra Leone
}

\begin{abstract}
Study Focus: This study only aimed at evaluating adolescents' physical education literacy level due developmental, humanistic and fitness factors, cased at four selected senior high schools in Bo, Southern Sierra Leone, West Africa.

Methods:Adolescents' physical education literacy level questionnaire (APELQ) was adopted and pre-tested as research instrument for testing the parameters. The variables were scaled using One-Sample t-Test of IBM-

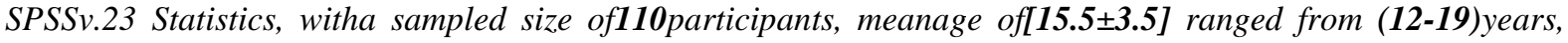
were selected using stratified and simple random sampling methods.

Results: The evaluated adolescents' physical education literacy statistical testresults showeda significant difference in meanand frequency $(\boldsymbol{F})$ scores for all tested variables with developmental factors scored lowest 23.8 \pm 5.9 with a frequency of 143 of pre-test and fitness factors scored highest36.0 \pm 4.9 with a frequency of 216 of pre-testin tables 2 and 6 respectively.The resultswere scaled @ 2-tailed significance of ${ }^{*} \boldsymbol{p}<0.000$ and $*{ }^{*} \times p<0.001$.

Conclusion and Recommendation:It was concluded that,agood number of adolescents lack the basic literacyof physical education asslated in their calculated values and responses. Giving due attention to the teaching and learning of Physical Education in schools, was strongly recommended by the researchers.
\end{abstract}

Keywords: PhysicalEducation, Literacy, Developmental, Humanistic andFitness Factors

\section{Introduction}

Physical Education (PE) is an educational course related to the physique of the human body, which encourages psychomotor learning in a play or movement exploration setting to promote health, which is very important to students' overall well-being, Anderson, D. (1989). The Centers for Disease Control and Preventions stated that, over the past three years' obesity in children (ages 2-5) and adolescents (ages 12-19) has doubled because of lack of quality physical education, activity and diet programs, which will benefit the lifestyle of young people and provide structure for students to improve fitness, positive choices and setting, and reaching goals, The Importance of Physical Education, (2016). Using new technology in Physical education is playing a big role in classes. One of the most affordable and effective is a simple video recorder. With the use of a video recorder, students can see the mistakes they're making in things such as a throwing motion or swinging form, and find it more effective than having someone try to explain what they are doing wrong, and then trying to correct it, Wang, L. et al. (2010). Educators also found the use of other technologies such as pedometers and heart rate monitors very successful, using them to make step and heart rate goals for students. Using heart rate monitors in physical education is important because it helps students understand how exercise affects their body, Woods, M. et al. (2008). Other technologies that can be used in physical education setting would include video projectors and GPS projectors to show students things such as proper form or how to play certain games. GPS systems can be used to get students active in an outdoor setting and can be used by teachers to show students a good way to stay fit within and outside of the classroom, Grimes, G. (2011). Another type of technology that is commonly used in physical education is pedometers, which is necessary to track how far a person is going, and also lets them know the number of steps on average they are making, Humankinetics.com (2010).

Through Physical Education or Human Kinetics and Health Education as it is called at NjalaUniversity, games and sports have been in existence in various parts of the world including Sierra Leone, in the form of physical activities (PA).Moreover, man's involvement in physical education was based on real life situations like food seeking from place to place and throwing objects to secure food, to keep wild animals' away, climbing 
trees to find shelter, put up defense against the attacks of other tribes in a bid to acquire more land and/or property and for man to preserve himself against the powers of witchcraft and herbalists, Bebeley,et al. (2008).In Sierra Leone,before independent era in 1961, one justifiable reason that led to the inclusion of Physical Education/Training at that time in the educational system by Christian Missionaries whose aim and objectives were to build churches and erect schools alongside in and outside Freetown the capital of Sierra Leone, was the boring and tiresome effect of pupils sitting in classrooms, reading, writing, and doing arithmetic, thus making them negatively reacting to teaching and learning activities, Bebeley,et al. (2008). Theinclusion of Physical Education/Training in the school's curriculum that was in existence by thenwas highly regimental since it was geared towards' Men Sana Inco Pore Sano (Latin), meaning a sound mind in a healthy body, Bebeley, et al. (2008). This was the position of Physical Education/Training in Sierra Leone until post independent era when Physical Education/Training became widely known as Physical Education, due to the fact that, researchers, educators and curriculum planners in Sierra Leone saw Physical Education/Training as an aspect of education that strongly supportthe promotionof not only an education of the physical but also through the physical, emphasizing on promoting social, physical, moral and intellectual abilities of the individual involve, Bebeley, et al.(2008).

In the late 1980's to early 1990's, researchers and curriculum planners in the health education sector in Sierra Leone and the Sub-Sahara Regions in West Africa, also deemed it necessary to include health education in the curriculum of physical education due to the fact that the health status of an individual cannot be devoid of physical activities (PA), hence the name Physical and Health Education came into existence, which was better organized and became an integral of the academic curriculum at all levels in pre-primary, primary, junior high schools, senior high schools, teacher's training colleges, polytechnics and Njala University, Bebeley, et al.(2008). Physical and Health Education was formally instituted as degree programme in the academic curriculum of Njala University,the then Njala University College, University of Sierra Leone in 1990, which was later transformed into Human Kinetics and Health Education pioneered by Laggao, S. A. (PhD) 2008.Human Kinetics and Health Education is an inclusive body in the curriculum of Njala University, under the School of Education, charged with the responsibility of offering Bachelor of Science in Education degree, Master of Science and Master of Art in Education with options Exercise Physiology and Sport Administration and Management, Bebeley, et al.(2008).However, due toscientifically guided steps by researchers, educators and curriculum planners in Sierra Leone and the Sub-Sahara Regions in West Africa, Human Kinetics/Physical and Health Education has gained momentum in the history and development of not only Sierra Leone but West Africa as a whole, Bebeley, et al. (2008).

This study only aimed atevaluating adolescents' physical education literacy level due developmental, humanistic and fitness factors, cased at four selected senior high schools in Bo, Southern Sierra Leone, West Africa.

\section{Research Participants:}

\section{Materials and Methods}

The research was conducted mainly on senior high school pupils with a sampled size of one hundred and ten $(\mathbf{n = 1 1 0})$,a mean and standard deviation age of [15.5 $\pm \mathbf{3 . 5}$ ] ranged from (12-19)years, were selected adopting the process of stratified and simple random sampling methods.

Survey Instrument:

Adolescents' physical education literacy level questionnaire (APELQ) was adopted and pre-tested as research instrument for testing the parameters on thirty pupils $(\mathbf{n = 3 0})$ from University Secondary School (USS) $\mathrm{Njala}$, usingthe test retest analysis of variance (ANOVA) technique,producinganintra-class correlation coefficient reliability (ICCR)of0.75-to-0.79, which was previously used by Bebeley,(2016).

\section{Procedure:}

The participantswere each given a questionnaire and instructed by the researchersto strictlymark the number[(0) for the answer (No)]and/or the number[(1) for the answer (Yes)]against eachoption variables as demanded during the pre-and-post-testsevaluation immediately after aten (10) minutes' interval of physical educationliteracy briefing regarding theoption variables under evaluation, adopting classroom face-to-face method.

Analysis:

The frequency, percentage, standard deviation, mean, 95\% confidence interval difference and OneSample t-Test fromIBM-SPSSv.23 Statistics, were used to compute, analyze and compare the results of the finding,which weretested @ 2-tailed significance level of $* \boldsymbol{p}<\mathbf{0 . 0 0 0}$ and $* * \boldsymbol{p}<\boldsymbol{0 . 0 0 1}$ with test-value of $\mathbf{0 . 0 5}$. 


\section{Results}

Table 1: Adolescents' Physical Educ. Literacy Level Due Developmental Factors $(n=110)$

\begin{tabular}{|c|c|c|c|c|}
\hline \multirow{2}{*}{$\begin{array}{l}\text { Do you Know that Physical Educ.Literacy Due Developmental Factors } \\
\text { can be Linked to: }\end{array}$} & \multicolumn{2}{|c|}{ Pre-Test } & \multicolumn{2}{|c|}{ Post-Test } \\
\hline & $\mathbf{n}$ & $\%$ & $\mathbf{n}$ & $\%$ \\
\hline Opportunity for Holistic Development? & 29 & 26 & 81 & 74 \\
\hline Opportunity for Competence? & 21 & 19 & 89 & 81 \\
\hline Opportunity for Socialization? & 32 & 29 & 78 & 71 \\
\hline Preparation for Integration of Experience? & 25 & 23 & 85 & 77 \\
\hline Preparation for Society and Social Change? & 19 & 17 & 91 & 83 \\
\hline Preparation for Self-Actualization? & 17 & 15 & 93 & 85 \\
\hline
\end{tabular}

Table 2:One-Sample t-Test for Phy. Educ. Literacy DueDevelopmental Factors $(n=110)$

\begin{tabular}{|c|c|c|c|c|c|c|c|}
\hline \multirow{2}{*}{$\begin{array}{c}\text { Vab. } \\
\text { (V) }\end{array}$} & \multirow{2}{*}{$\begin{array}{l}\text { Freq. } \\
\text { (F) }\end{array}$} & \multirow{2}{*}{$\begin{array}{l}\text { Mean } \\
\text { Scores }\end{array}$} & \multirow{2}{*}{$\begin{array}{l}\text { Std. } \\
\text { Dev. }\end{array}$} & \multirow{2}{*}{$\begin{array}{l}\text { t-Test } \\
\text { Scores }\end{array}$} & \multirow{2}{*}{$\begin{array}{l}\text { 2-tailed } \\
\text { Sig. }\end{array}$} & \multicolumn{2}{|c|}{ 95\% CID } \\
\hline & & & & & & Lower & Upper \\
\hline Pre-Test & 143 & 23.8333 & 5.87934 & 09.909 & 0.000 & 17.6133 & 29.9533 \\
\hline Post-Test & 517 & 86.1667 & 5.87934 & 35.878 & 0.000 & 79.9467 & 92.2867 \\
\hline
\end{tabular}

Table 3:Adolescents' Physical Educ. Literacy Level Due Humanistic Factors ( $n=110$ )

\begin{tabular}{|l|c|c|c|c|}
\hline \multicolumn{2}{|c|}{$\begin{array}{c}\text { Do you Know that Physical Educ. Literacy Due Humanistic } \\
\text { Factors can be Linked to: }\end{array}$} & \multicolumn{2}{c|}{ Pre-Test } & \multicolumn{3}{c|}{ Post-Test } \\
\cline { 2 - 5 } & $\mathbf{n}$ & $\mathbf{\%}$ & $\mathbf{n}$ & $\mathbf{\%}$ \\
\hline Individual Uniqueness? & 30 & 27 & 80 & 73 \\
\hline Sense of Community? & 23 & 21 & 87 & 79 \\
\hline Active Playful Spirit? & 41 & 37 & 69 & 63 \\
\hline Stages of Development in Self-Direction? & 19 & 17 & 91 & 83 \\
\hline Expanding Self-Awareness? & 13 & 12 & 97 & 88 \\
\hline Social Change\& Preparation for Society? & 27 & 25 & 83 & 75 \\
\hline
\end{tabular}

Table 4:One-Sample t-Test for Phy.Educ. Literacy Due Humanistic Factors $(n=110)$

\begin{tabular}{|c|c|c|c|c|c|c|c|}
\hline \multirow{2}{*}{$\begin{array}{l}\text { Vab. } \\
\text { (V) }\end{array}$} & \multirow{2}{*}{$\begin{array}{c}\text { Freq. } \\
\text { (F) }\end{array}$} & \multirow{2}{*}{$\begin{array}{c}\text { Mean } \\
\text { Scores }\end{array}$} & \multirow{2}{*}{$\begin{array}{l}\text { Std. } \\
\text { Dev. }\end{array}$} & \multirow{2}{*}{$\begin{array}{l}\text { t-Test } \\
\text { Scores }\end{array}$} & \multirow{2}{*}{$\begin{array}{l}\text { 2-tailed } \\
\text { Sig. }\end{array}$} & \multicolumn{2}{|c|}{ 95\% CID } \\
\hline & & & & & & Lower & Upper \\
\hline Pre-Test & 153 & 25.5000 & 9.66954 & 06.447 & 0.001 & 15.3024 & 35.5976 \\
\hline Post-Test & 507 & 84.5000 & 9.66954 & 21.393 & 0.000 & 74.3024 & 94.5976 \\
\hline
\end{tabular}

Table 5:Adolescents' Physical Educ. Literacy Level Due Fitness Factors $(n=110)$

\begin{tabular}{|l|c|c|c|c|}
\hline \multicolumn{1}{|c|}{ Do you Know that Physical Educ. Literacy Due Fitness } & \multicolumn{2}{c|}{ Pre-Test } & \multicolumn{2}{c|}{ Post-Test } \\
\cline { 2 - 5 } \multicolumn{1}{r|}{ Factors can be Linked to: } & n & \% & n & \% \\
\hline Unique Contribution of Health? & 39 & 35 & 71 & 65 \\
\hline Skills in Activities with Health Benefits? & 33 & 30 & 77 & 70 \\
\hline Commitment to Regular Exercise? & 43 & 39 & 67 & 61 \\
\hline Components of Health-Related Fitness? & 37 & 34 & 73 & 66 \\
\hline Knowledge and Activities Related to Fitness? & 35 & 32 & 75 & 68 \\
\hline Disciplinary Mastery? & 29 & 26 & 81 & 74 \\
\hline
\end{tabular}

Table 6:One-Sample t-Test for Phy.Educ. Literacy Due Fitness Factors ( $n=110)$

\begin{tabular}{|c|c|c|c|c|c|c|c|}
\hline \multirow{2}{*}{$\begin{array}{l}\text { Vab. } \\
\text { (V) }\end{array}$} & \multirow{2}{*}{$\begin{array}{c}\text { Freq. } \\
\text { (F) }\end{array}$} & \multirow{2}{*}{$\begin{array}{l}\text { Mean } \\
\text { Scores }\end{array}$} & \multirow{2}{*}{$\begin{array}{l}\text { Std. } \\
\text { Dev. }\end{array}$} & \multirow{2}{*}{$\begin{array}{l}\text { t-Test } \\
\text { Scores }\end{array}$} & \multirow{2}{*}{$\begin{array}{l}\text { 2-tailed } \\
\text { Sig. }\end{array}$} & \multicolumn{2}{|c|}{$95 \%$ CID } \\
\hline & & & & & & Lower & Upper \\
\hline Pre-Test & 216 & 36.0000 & 4.85798 & 18.127 & 0.000 & 30.8519 & 41.0481 \\
\hline Post-Test & 444 & 74.0000 & 4.85798 & 37.287 & 0.000 & 68.8519 & 79.0481 \\
\hline
\end{tabular}

\section{Discussion}

The UNESCO Charter on Physical Education and Sports recognizes the inalienable right of every child to participate in physical activity irrespective of race, gender, religion and physical state. Physical Education provides opportunities for the acquisition of comprehensive knowledge, attitudes and skills, which stimulate individual and group consciousness, UNESCO (2004). The comparatively analysed results from the grouped frequency level of respondents' physical education literacy of all tested variables betweenpre-test and post-test evaluation processdue developmental, humanistic and fitness factors as computed, analysed, compared and slated in tables two, four and six,showed a significant difference in their respective grouped scores.

The significant difference in t-Test scores and 95\% confidence interval difference scores recorded betweenpre-test andpost-testresults indicated rigidly, the low level of adolescents' physical education literacy with reference to the tested variables, which was also noted inindividually computed, analysed and compared frequencies and percentages slated in tables one, threeand five respectively. 
However, insimilar research, UNESCO (2004) reported that, many projects and initiatives planned for International Year of Sport and Physical Education (IYSPE) 2005, focus on communications and advocacy, while others will employ the potential of sports to enhance existing programmes, especially those that are children, adolescents and youths oriented by integrating into their work toward peace and development, in partnership with UNDP, International Labour Organization (ILO), United Nations Environmental Programme (UNEP), UNESCO and UNICEF.In Sierra Leone, according toUNESCO (2004), physical education and sports offered an avenue for child soldiers to control aggression and build positive relationships with adults and peers in society.In partnership with the NGO Right to Play,UNICEF incorporated sports and play into its community based reintegration programme, building a network of coaches who implemented sports programmes and gave youths a sense of belonging through crucial community connections.

\section{Conclusion and Recommendation}

Based on the results, it is concluded thata significant difference was observed in comparison betweenpre-test andpost-test scores for alltested variables during the evaluation process regarding adolescents' physicaleducation literacy levelslated in frequencies, percentages, mean scores, $95 \%$ confidence interval difference scores and calculated One-Sample t-Test scores. However, giving due attention to the teaching and learning of physical education in schools, was strongly recommended by the researchers.

\section{Acknowledgement}

The authorsexpress thanks and appreciation to all staff and pupils of the four-selected senior high schools in Bo, Sierra Leone, whose immense co-operation rendered this study to fruition.

\section{References}

[1.] Anderson, D. (1989). The Discipline and the Profession. Foundations of Canadian Physical Education, Recreation, and Sports Studies. Dubuque, IA: Wm. C. Brown Publishers.

[2.] Bebeley, S. J. (2016). Adolescents' Knowledge about the Contraindications of Muscle Weakness Due Central Fatigue, Peripheral Fatigue and Lactic Acid as Health Education Strategy in Lifestyle Management. PARIPEX-Indian Journal of Research:5 (4): 2-4

[3.] Bebeley, S. J. and Laggao, S. A. (2008). Attitude of students at Njala University Bo Campus, towards Physical Health Education. An unpublished dissertation:Department of Human Kinetics and Health Education, School of Education, Njala University.

[4.] Grimes, G. (2011). Interview by M Massey [Personal Interview]. http://global.bing.com/videos/search? $\mathrm{q}=$ grimes $\% 2 \mathrm{c}+\mathrm{g} .+2011+$ november $+2+$ interview $+\mathrm{by}+\mathrm{m}+$ massey\&qpvt=Grimes $\% 2 \mathrm{c}+\mathrm{G} .+2011+$ November $+2+\mathrm{interview}+\mathrm{by}+\mathrm{M}+\mathrm{Ma}$ SSey\&FORM=VDRE

[5.] Humankinetics.com (2010). Using pedometers to assess physical activity participation levels.http://cncc.bingj.com/cache.aspx? $\mathrm{q}=\% 22 \mathrm{using}+$ pedometers+to+assess+physical+activity+participation+levels $\% 22 \& \mathrm{~d}=4730594541636263 \& \mathrm{mkt}=\mathrm{zh}-$ CN\&setlang=en-US\&w=g7I8UrKk1lhnOcaSyfacYM-UsqIBxqNT

[6.] Jewett, A. E. and Bain, L. L. (1985).The Curriculum Process in Physical Education, pp. 80-82. http://www.ed.gov .nl.ca/edu/k12/curriculum/documents/physed/ch4.pdf

[7.] The Importance of Physical Education. (2016). Retrieved fromhttp://www.veanea.org/home/1000.htm

[8.] UNESCO Conference of Ministers of Sports and Physical Education, (2004). Developmentof sport in view of IYSPE 2005 in Athens. https://www.un.org/sport2005/a_year/facts.pdf

[9.] Wang, L., Myers, D. and Yanes, M. (2010). Creating student-centered learning experience through the assistance of high-end technology in physical education. Journal of Instructional Psychology, 37(4), 352-356.

[10.] Woods, M., Karp, G., Goc, H. and Perlman, D. (2008). Physical educators' usage. PhysicalEducator, 65(2), 82-99. 